\title{
Financial Performance Indicators: The Impact of Company's Lifetime and Industry Type
}

\author{
Tijana Obradović \\ Department of Financial management \\ and accounting \\ Faculty of Organisational Sciences \\ Belgrade, Serbia \\ tijana.obradovic@fon.bg.ac.rs
}

\author{
Veljko Dmitrović \\ Department of Financial management \\ and accounting \\ Faculty of Organisational Sciences \\ Belgrade, Serbia \\ veljko.dmitrovic@fon.bg.ac.rs
}

\author{
Marija Kuzmanović \\ Department of Operations Research \\ and Statistics \\ Faculty of Organisational Sciences \\ Belgrade, Serbia \\ marija.kuzmanovic@fon.bg.ac.rs
}

\begin{abstract}
The formula for high financial performance is a never-ending story. A significant chapter of that story is the one dealing with causality and interactions between specific financial performance indicators and the organisation's characteristics. This paper investigates the financial performance indicators of 130 best-performing companies using Forbes's Global top performers list to create a foundation and a tool for managing companies' success by managing a concrete set of financial indicators. We examined 98 financial performance indicators, for a five years period, analysing companies originating from 21 countries and operating in 23 industries. Specific attention is paid to research questions whether there is a correlation between of financial indicators values and companies' age and industry. The goal is to come to a set of financial performance indicators benchmarks that would lead to a successful business if followed. Those benchmarks, set by the age and industry type, can serve as a target value for the comparable organisations, which fulfilment would ensure business becoming a success story.
\end{abstract}

Keywords-financial performance, indicator, company's age, industry type

\section{INTRODUCTION}

Performance can be perceived as a record of achieving outcomes, in the corporate context, it can be considered as a business outcome [1] or achievement, result. On the other hand, performance can be considered as behaviour or the way of undertaking business [2]. The shape and state of every business operation are changing daily, and performance indicators inform managers about the most important points of business operations that require immediate attention [3]. More importantly, performance indicators provide guidelines for strategic decision making.

Performances clarify the manner in which an organisation operates in the light of its goals, while performance indicators provide a tool to measure and objectively explain them. Performance analysis is a systematic diagnosis of the company's wealth and represents the main tool for every manager responsible for generating profit, particularly for financial manager [4].
Organisations use performance indicators for countless purposes, and those purposes vary in time and from situation to situation. But whatever situation is, and whatever decision is to be made, financial performance indicators are an inevitable source of valuable information for every organisation.

Financial indicators are often used for evaluation of past performance, but their true value should be in enabling possible prediction of the future ones. Every predictability in their values can be a priceless source of information and valuable guide for managers in their everyday operations, along with their strategic thinking.

With the intention of using financial performance indicators as a tool for managing an organisation, it is necessary to establish conditionality and interdependence between certain financial indicators and different organisational parameters. In this paper, we examined the correlation between the organisation's high performances and its age and industry type. The aim is to determine which financial indicators are manageable, and which are simply defined by the organisation's age or industry it belongs. In this way, decision-maker can easily differentiate between relevant and irrelevant performance indicators, which is of enormous help having in mind the almost endless list of possible financial performance indicators that can be tracked and analysed. It is sufficient to highlight the importance of time and money-saving that can be ensured this way. This information is precious in today's world of continuous lack of manager's time so that he or she can devote to manageable factors, instead of dealing with a bunch of unmanageable indicators.

\section{GLOBAL TOP PERFORMERS}

One of the challenges we faced trying to identify successful financial indicators, that could serve as a benchmark was to select the right choice of broadly accepted successful companies as so. In the light of our research needs, the most relevant organisations, in terms of performances, seemed to be those from Forbes's Global Top Performers list [5]. The Global 
Top Performers list consists of 130 companies, selected from Forbes's Global 2000 list, as the list of companies with the best overall performances. To calculate financial performance indicators, of those best performance companies, we used financial reports from six years period for these organisations gathered from Morningstar, Inc [6]. It was almost natural to choose Morningstar for data inputs because Forbs creates Global Top Performers listing based on data provided by Morningstar. The sample is made of 113 organisations from 23 different industries. We calculate 98 financial performance indicators for a five years period of time (using financial reports for those organisations for six yeast period).

The organisations from the sample come from the following industries:

1. Aerospace \& Defence,

2. Business Services \& Supplies,

3. Capital Goods,

4. Chemicals,

5. Conglomerates,

6. Construction,

7. Consumer Durables,

8. Drugs and Biotechnology,

9. Food Markets,

10. Food, Drink \& Tobacco,

11. Health Care Equipment,

12. Hotels, Restaurants and Leisure,

13. Household/Personal Products,

14. Materials,

15. Media,

16. Oil \& Gas Operations,

17. Retailing,

18. Semiconductors,

19. Software and Services,

20. Tech Hardware \& Equip,

21. Telecom Services,

22. Transportation and

23. Utilities.

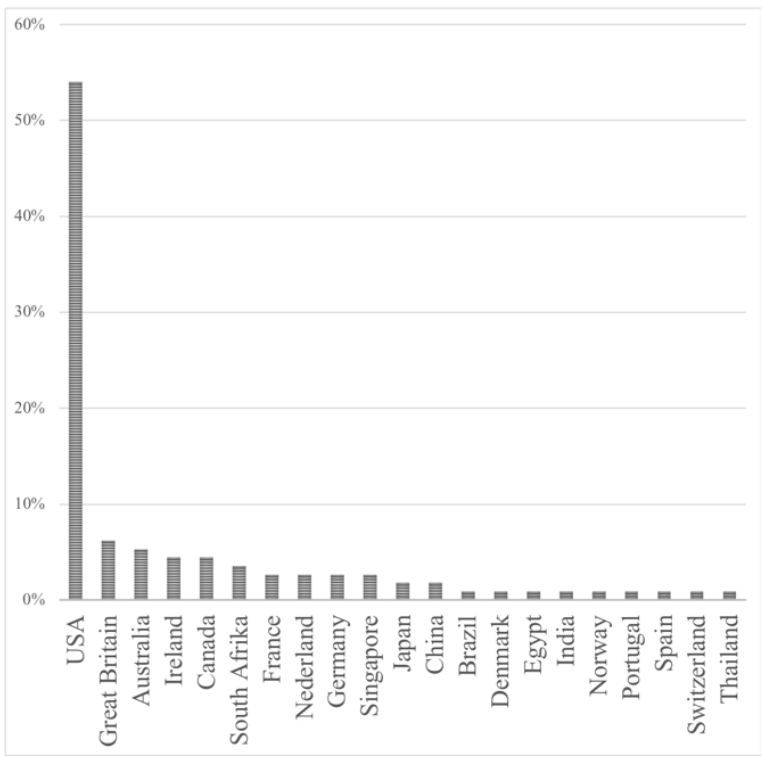

Fig. 1. Country origin share of the organisations from the sample
Organisations with the best performances originate from 21 different countries. In alphabetical order, organisations are from Australia, Brazil, Canada, China, Denmark, Egypt, France, Germany, Great Britain, India, Ireland, Japan, Nederland, Norway, Portugal, USA, Singapore, South Afrika, Spain, Switzerland, Thailand, Fig. 1.

An interesting fact is that $54 \%$ of companies from the sample comes from the USA, meaning that the majority of companies that have high performances originates from the USA.

The second parameter we examined is a company's age, and it appears that the age of sample organisations is considerably diversified. Global high performers turn out to be organisations with long business tradition, lasting for more than two centuries, as well as newly established companies, lasting for less than a decade.

Even though there are some young companies on the list, the arithmetic mean for the company's age is 66,8 years, with a standard deviation of 45,91 [7].

With the aim of discovering the correlation between financial performance indicators of highperformance companies and the company's age and industry type, we analysed 98 financial indicators, exploring organisation's profitability, liquidity, activity, financial structure and market ratios, for five years period, based on financial reports from six business years.

\section{CORRELATION BETWEEN THE COMPANY'S AGE AND THE VALUE OF FINANCIAL PERFORMANCE INDICATORS}

There are some honourably old organisations in the Global top Performers list. Amazingly, twenty of them, or about 18 per cent of the sample, have more than one hundred years lifespan. In other words, they exist on the market for more than a century now.

Correspondingly, the research sample comprises some of the considerably young companies too. However, only one of them is less than ten years old, and about fifteen of the best performers, or about 13 per cent, are less than twenty years old.

To examine the possible relationship between the value of individual financial performance indicators and company's age, we used Spearman's correlation test, since it enables establishing the correlation between some items, without determining linear interdependence among them [7].

The results show that there are several financial indicators that are correlated to the company's age. We will explore them in additional text.

Quick ratio (table I) is clearly dependent on the company's age, and that correlation coefficient is a negative one. In other words, younger companies have a higher quick ratio. The conclusion is that younger companies have a higher level of liquid assets for 
meeting current liabilities than companies that exist for a longer time on the market [7].

TABLE I. CORRELATION BETWEEN QUICK RATIO AND THE AGE OF A COMPANY

\begin{tabular}{|c|c|c|}
\hline \multicolumn{3}{|c|}{ Quick ratio } \\
\hline & Correlation Coefficient & Sig. (2-tailed) \\
\hline Year 1 & $-0,208 *$ & 0,02687804 \\
\hline Year 2 & $-0,173$ & 0,06800000 \\
\hline Year 3 & $-0,199 *$ & 0,03427247 \\
\hline Year 4 & $-0,257 * *$ & 0,00598979 \\
\hline Year 5 & $-0,242 * *$ & 0,00980903 \\
\hline
\end{tabular}

The cash ratio (table II) is also correlated to the company's age, end that correlation coefficient is a negative one. Older companies have lower cash ratio [7].

TABLE II. CORRELATION BETWEEN CASH RATIO AND THE AGE OF A COMPANY

\begin{tabular}{|c|c|c|}
\hline \multicolumn{3}{|c|}{ Cash ratio } \\
\hline & Correlation Coefficient & Sig. (2-tailed) \\
\hline Year 1 & $-0,324 * *$ & 0,00047321 \\
\hline Year 2 & $-0,263 * *$ & 0,00500000 \\
\hline Year 3 & $-0,302 * *$ & 0,00113255 \\
\hline Year 4 & $-0,326^{* *}$ & 0,00042125 \\
\hline Year 5 & $-0,322 * *$ & 0,00050965 \\
\hline
\end{tabular}

Property, plant, and equipment turnover ratio has a positive correlation with the age of the company (table III). The research has shown that the older the company is, the higher property, plant, and equipment turnover ratio seems to be [7].

TABLE III. CORRELATION BETWEEN PROPERTY, PLANT, AND EQUIPMENT TURNOVER RATIO AND THE AGE OF A COMPANY

\begin{tabular}{|c|c|c|}
\hline \multicolumn{3}{|c|}{ Property, plant, and equipment turnover ratio } \\
\hline & Correlation Coefficient & Sig. (2-tailed) \\
\hline Year 1 & $-0,283 * *$ & 0,00234405 \\
\hline Year 2 & $-0,198 *$ & 0,03500000 \\
\hline Year 3 & $-0,193 *$ & 0,04084948 \\
\hline Year 4 & $-0,202 *$ & 0,03159191 \\
\hline Year 5 & $-0,239^{*}$ & 0,01093915 \\
\hline
\end{tabular}

Oppositely to property, plant, and equipment turnover ratio, cash turnover ratio has a negative correlation coefficient with the company's age (table IV). It means that younger companies have a faster turnover ratio, and the ratio becomes slower as the company grows older. There is a very high confidence interval to support this claim. The possibility that younger companies have slower cash turnover than the older ones is less than $1 \%$ [7].

Net debt to total equity ratio is also correlated to the age of the company, in a positive way (table V).
Older companies have a much higher level of debt comparing to total assets than the younger companies do [7].

TABLE IV. CORRELATION BETWEEN A CASH TURNOVER RATIO AND THE AGE OF A COMPANY

\begin{tabular}{|c|c|c|}
\hline \multicolumn{3}{|c|}{ Cash turnover ratio } \\
\hline & Correlation Coefficient & Sig. (2-tailed) \\
\hline Year 1 & $0,326 * *$ & 0,00042941 \\
\hline Year 2 & $0,308^{* *}$ & 0,00100000 \\
\hline Year 3 & $0,319 * *$ & 0,00056520 \\
\hline Year 4 & $0,343^{* *}$ & 0,00020154 \\
\hline Year 5 & $0,357^{* *}$ & 0,00010245 \\
\hline \multicolumn{3}{|c|}{$*$ - Confidence interval is 95\% } \\
** - Confidence interval is $99 \%$ \\
$\mathrm{~N}=113$
\end{tabular}

TABLE V. CORRELATION BETWEEN NET DEBT TO TOTAL EQUITY RATIO AND AGE OF THE COMPANY

\begin{tabular}{|c|c|c|}
\hline \multicolumn{3}{|c|}{ Net debt to total equity ratio } \\
\hline & Correlation Coefficient & Sig. (2-tailed) \\
\hline Year 1 & $0,238^{*}$ & 0,01124802 \\
\hline Year 2 & $0,269^{* *}$ & 0,00400000 \\
\hline Year 3 & $0,251^{* *}$ & 0,00729550 \\
\hline Year 4 & $0,248^{* *}$ & 0,00803120 \\
\hline Year 5 & $0,266^{* *}$ & 0,00439042 \\
\hline \multicolumn{3}{|c|}{$\begin{array}{c}* \text { - Confidence interval is } 95 \% \\
\text { * - Confidence interval is } 99 \% \\
\mathrm{~N}=113\end{array}$} \\
\end{tabular}

As the company grows older, the cash flow to capital expenditures ratio becomes lower (table VI). This means that there is a negative correlation coefficient between cash flow to capital expenditures ratio and a company's age [7].

TABLE VI. CORRELATION BETWEEN CASH FLOW TO CAPITAL EXPENDITURES RATIO AND AGE OF THE COMPANY

\begin{tabular}{|c|c|c|}
\hline \multicolumn{3}{|c|}{ Cash flow to capital expenditures ratio } \\
\hline & Correlation Coefficient & Sig. (2-tailed) \\
\hline Year 1 & $-0,276^{* *}$ & 0,00312167 \\
\hline Year 2 & $-0,254^{* *}$ & 0,00700000 \\
\hline Year 3 & $-0,267^{* *}$ & 0,00425780 \\
\hline Year 4 & $-0,211^{*}$ & 0,02457926 \\
\hline Year 5 & $-0,155$ & 0,10192747 \\
\hline \multicolumn{3}{|c|}{$*$ - Confidence interval is $95 \%$} \\
$* *$ - Confidence interval is $99 \%$ \\
$\mathrm{~N}=113$
\end{tabular}

TABLE VII. CORRELATION BETWEEN CASH FLOW TO PROFIT RATIO AND AGE OF THE COMPANY

\begin{tabular}{|c|c|c|}
\hline \multicolumn{3}{|c|}{ Cash flow to profit ratio } \\
\hline & Correlation Coefficient & Sig. (2-tailed) \\
\hline Year 1 & $-0,371 * *$ & $5,3557 \mathrm{E}-05$ \\
\hline Year 2 & $-0,337 * *$ & 0,00000000 \\
\hline Year 3 & $-0,353^{* *} *$ & 0,00012550 \\
\hline Year 4 & $-0,193 *$ & 0,04050196 \\
\hline Year 5 & $-0,043$ & 0,64817832 \\
\hline
\end{tabular}

In the same way as a cash flow to capital expenditures, cash flow to profit ratio has higher values for the younger companies and the lower values for the older ones (table VII). Cash flow to profit ratio 
and the age of the company have a negative correlation coefficient [7].

The cash reinvestment ratio shows statistical interdependence with the age of a company (table VIII). The older companies have higher cash reinvestment ratio than the young ones [7]. The younger the company is, the higher the value of this ratio it has.

TABLE VIII. CORRELATION BETWEEN CASH REINVESTMENT RATIO AND AGE OF THE COMPANY

\begin{tabular}{|c|c|c|}
\hline \multicolumn{3}{|c|}{ Cash reinvestment ratio } \\
\hline & Correlation Coefficient & Sig. (2-tailed) \\
\hline Year 1 & $-0,284 * *$ & 0,00228562 \\
\hline Year 2 & $-0,282 * *$ & 0,00200000 \\
\hline Year 3 & 0,00228562 & 0,00303656 \\
\hline Year 4 & $-0,215 *$ & 0,02193047 \\
\hline Year 5 & $-0,299 * *$ & 0,00130158 \\
\hline \multicolumn{3}{|c|}{ * - Confidence interval is $95 \%$} \\
$* *$ - Confidence interval is $99 \%$ \\
$\mathrm{~N}=113$
\end{tabular}

And finally, the last performance indicator that is in correlation with the company age is inventory to total assets ratio. The correlation between the company's age and inventory to total assets ratio is positive (table IX), which means that older companies keep much less inventory than the young one, as a percentage of total assets [7].

TABLE IX. CORRELATION BETWEEN INVENTORY TO TOTAL ASSETS RATIO AND AGE OF THE COMPANY

\begin{tabular}{|c|c|c|}
\hline & \multicolumn{3}{|c|}{ Inventory to total assets ratio } \\
\hline & Correlation Coefficient & Sig. (2-tailed) \\
\hline Year 1 & $0,235^{*}$ & 0,01223340 \\
\hline Year 2 & $0,241^{*}$ & 0,01000000 \\
\hline Year 3 & $0,256^{* *}$ & 0,00619232 \\
\hline Year 4 & $0,198^{*}$ & 0,03561557 \\
\hline Year 5 & $0,223^{*}$ & 0,01784570 \\
\hline \multicolumn{3}{|c|}{$\begin{array}{c}* \text { - Confidence interval is } 95 \% \\
\text { ** - Confidence interval is } 99 \% \\
\mathrm{~N}=113\end{array}$} \\
\hline
\end{tabular}

Although the company's age as a factor that drives the values of the financial indicator has proved to be significant for a small number of ratios, the noteworthy conclusions can be driven from them, concerning the way in which young companies run business compared to the companies with a long tradition. These correlations can be of great help in managing companies through the different phases of an organisational life cycle [7].

\section{CORRELATION BETWEEN THE INDUSTRY TYPE AND THE VALUES OF FINANCIAL PERFORMANCE INDICATORS}

It is highly valuable in the analysis of financial indicators to determine how the values of financial performance indicators for a particular organisation depend on the nature of the industry it belongs to. For this type of analysis, we used an analysis of variance test, known as the ANOVA test. ANOVA test was applied to determine whether there is a significant difference between values of individual financial performance indicators among different industries [7].

We found that for most financial indicators, their value significantly varies along with the industry the organisation belongs. More precisely, the industry did not have an impact on the values of only $21 \%$ of all financial performance indicator [7]. These indicators are: effective tax rate, working capital turnover ratio, operating working capital ratio, financial leverage, ratio debt to equity ratio, long term debt to equity ratio, net debt to equity ratio, fixed assets to equity ratio, financial leverage index, operating leverage factor, financial leverage factor, total leverage factor, enterprise value to EBITDA ratio, market to book value, premium (discount) to net assets value, cash return on equity, cash flow to profit ratio, revenue growth rate, net profit growth rate, sustainable growth rate and net debt to free cash flow ratio.

Statistical analysis has shown that for almost fourfifths of analysed indicators, the industry has a significant influence on their values. In further analysis, we applied multiple comparison test in order to determine the exact industries that have a significant difference in values of financial indicators, for each indicator separately. We found which industries concerning each financial indicator significantly differ. The result of this analysis is set of 77 tables, 529 rows and 8 columns each, and therefore cannot be presented in this paper, but it is certainly great base for further research [7].

\section{CONCLUSION}

It is well known that financial performance indicators have a great value for every organisation and serve a countless number of purposes. They are control marks for past performances, but more importantly, they are guidelines for future decision, strategic planning and thinking. Financial indicators, in some sense, can be seen as parameters that describe and explain certain industry, and our goal was to find those values that should serve as a recommendation for all companies from a particular industry.

In order for financial indicators to be as useful as possible, it is essential to find a way to evaluate whether it is good or bad and to have some benchmark for comparison. In this paper, we were trying to establish interdependence between values of financial indicators and the organisational lifetime and industry type. We wanted to observe companies, to see whether their high performances of Global Top Performers companies are in correlation to their age, or to the industry they belong. In order to archive that, we examined the areas of business that are influenced by the company's lifespan or the type of industry.

Interestingly, it was shown that there is interconnection between an only small number of financial indicator and the age of the company. 
Majority of these indicators are measuring liquidity or evaluating current cashflow.

When exploring the correlation between values of financial performance indicators and industry type, the situation is quite the opposite. The minority of financial indicators are not correlated to the company's industry type.

These findings are useful for improvement of financial management practice, by driving business operations toward anticipated and projected values of financial performance indicators, for certain organisation's age and industry type.

By knowing the expected or desired values of financial indicators for certain type of organisation, managers can define and follow the chosen strategy and this strategy can be tracked by choosing the right projects in the light of their contribution to the target values of financial indicators.

Since the amount of data gathered through this research is substantial, given the fact that we examined over eighty indicators for 113 organisations from 23 different industries, the number of possible interconnections aspirer to infinity. As an illustration, solely the analysis of the correlation between each financial indicator separately, and type of industry results in 77 tables with 325,864 data. This opens the space for further research in certain industry, geographic region, company's lifespan and their relationships.

\section{ACKNOWLEDGEMENT}

This paper is a result of the Project No. 179081 funded by Ministry of Education and Science of the Republic of Serbia: Researching Contemporary Tendencies of Strategic Management Using Specialized Management Disciplines in Function of Competitiveness of Serbian Economy.

\section{REFERENCES}

[1] H. K. Bernadin, J. S. Kane, S. Ross, J. D. Spina, and D. L. Johnson, "Performance appraisal design, development and implementation," in "Handbook of Human Resource Management" G. R. Ferris, S. D. Rosen, and D. J. Barnum, eds. Cambridge, MA: Blackwell, 1995.

[2] M. Armstrong, “Armstrong's Handbook of Performance Management: An Evidence-Based Guide to Delivering High Performance", London: Kogan Page Ltd, 2009.

[3] C. Walsh, "Key management ratios: The clearest guide to the critical numbers that drive your business", Harlow: Pearson's Education Limited, 2006.

[4] T. Hagos, and G. Pal, "The means of analysis and evaluation for corporate performances", Annales Universitatis Apulensis Series Oeconomica, pp. 438-449, 2010.

[5] Forbes, Global High Performers, from www.forbes.com: https://www.forbes.com/lists/global-high-performers-fulllist.html, 2019.

[6] I. Morningstar, Inc. Fact Sheet. Retrieved November 6, 2013, from Corporate Morningstar Web site http://corporate.morningstar.com/us/documents/MarketingFac tSheets/AboutMorningstar-Factsheet.pdf, August 2013
[7] T. A. Obradović, "Business management concept based on financial performances indicators", doctoral dissertation University of Belgrade, Faculty of Organisational Sciences, 2014 